\title{
Bencana Alam Banjir Dan Tanah Lonsor Di Kabupaten Sentani Jayapura Dalam Prespektif Green Criminology
}

\author{
David Hardiago ${ }^{1}$, Rani Fadhila Syafrinaldi ${ }^{2}$ \\ 1. Faculty of Law, Universitas Gajah Mada. E-mail: davidhardiago@mail.ugm.ac.id \\ 2. Faculty of Law, Universitas Gajah Mada. E-mail: raniyafrinaldi@mail.ugm.ac.id
}

\begin{abstract}
This article aims to analyze two main problems related to the connection between floods and landslides that occurred in Sentani Jayapura Regency with green criminology discipline as the main approach perspective. This paper also offer projection as a means of prevention of environmental damage that has an impact on the natural disaster. This research uses a multi-method research technique (triangular method), which combines more than one research technique or strategy to study one or several related phenomena. The conclusion, in general, consists of two main parts. First, the connection between flood and landslide natural disasters in Sentani Jayapura Regency with green criminology, lies in the scope of green criminology in relation to factors in factual incidents in the example cases raised. Second, the means of prevention as a projection offer, in outline it consists of several main points. First, restoring the forest area according to its function. Second, conduct a spatial review based on considerations of disaster risk reduction and develop an adaptation scheme at the point of flooding. Third, internalization of land rehabilitation programs in the upstream and middle watersheds (DAS), especially forest areas, into program indications for spatial planning. Fourth, internalization of the soil and water conservation program in the form of Water Drainage (SPA) in agricultural land and settlements to improve regulation so as to reduce the potential for landslides and water accumulation in a short time. Fifth, socialization to the public by providing an understanding of green criminology and the importance of environmental responsibility.
\end{abstract}

Keywords: Natural Disasters, Sentani Floods, Green Criminology

\section{Pendahuluan}

Jus istud non humanis generis propium est, sed omnium animalium, quae in caelo, quae in terra, quae in mari nascuntur yang berarti bahwa hukum bukan spesies manusia, tetapi hukum mengatur semua yang ada di udara, di darat, maupun di laut. ${ }^{1}$ Berangkat dari asas hukum tersebut, yang selanjutnya merumuskan ketiga elemen di atas (pengaturan mengenai udara, darat, dan laut) dalam suatu istilah hukum umum dikualifikasikan sebagai instrument pengelolaan lingkungan hidup.

Secara mendasar, instrument pengelolaan lingkungan hidup dalam lingkup penegertian lingkungan memiliki beragam definisi. Namun sebagai gambaran awal, dapat dijelaskan bahwa lingkungan diartikan sebagai "kombinasi antara kondisi fisik dan non fisik, yang cakupannya meliputi segala hal dan keadaan, serta mencangkup

\footnotetext{
${ }^{1}$ Eddy O.S Hiariej, 2018, Asas-Asas Hukum: Bahan Ajar Teori dan Filsafat Hukum, Fakultas Hukum, Universitas Gadjah Mada.
} 
eksistensi manusia dan sekitarnya yang pada akhirnya mempengaruhi kelangsungan peri kehidupan manusia itu sendiri." 2

Pengertian mendasar dari lingkungan sebagaimana yang diuraikan di atas, selanjutnya diejawantahkan lebih lanjut di dalam Undang-Undang Nomor 32 Tahun 2009 tentang Perlindungan dan Pengelolaan Lingkungan Hidup (selanjutnya disebut UU PPLH). Sehingga, dapat dikemukakan di awal bahwa regulasi hukum positif di Indonesia yang memandang lingkungan (hidup) sebagai "kesatuan ruang dengan semua benda, daya, keadaan, dan makhluk hidup, termasuk manusia dan perilakunya, yang mempengaruhi alam itu sendiri, kejahatan lingkungan hidup, kelangsungan perikehidupan, dan kesejahteraan manusia serta makhluk hidup lain,"3 sejatinya bentuk lanjutan dalam suatu produk hukum positif dari definisi lingkungan yang telah ada sebelumnya.

Dari pemaparan di atas, menarik perhatian penulis untuk mempertanyakan mengapa instrumen pengelolaan lingkungan hidup menjadi sesuatu yang penting dan dibutuhkan, serta harus dituangkan dalam bentuk suatu produk hukum positif.

Pada suatu hipotesa, dalam rangka merespon pertanyaan hukum tersebut lahirlah tanggapan yang menyatakan bahwa pemikiran awal yang mendasari perlunya instrumen hukum pengelolaan lingkungan hidup, dikarenakan lahirnya kesadaran bahwa keadaan kualitas lingkungan sangat terkait dengan keberadaan manusia beserta segala aktifitasnya. Sebab, "manusia dan perilakunyalah yang dapat mempengaruhi, baik alam itu sendiri, kelangsungan peri kehidupan maupun kesejahteraan makhluk lainnya."4

Artinya, dengan peran besar atas perilaku manusia yang mempengaruhi keberlangsungan lingkungan hidup, hal inilah yang selanjutnya menjadi dasar utama mengapa perlu kirannya hal tersebut untuk diatur yang ditujukan guna melindungi keberlangsugan lingkungan hidup yang ada. Dengan kata lain, keberlangsungan lingkungan hidup yang dipengaruhi oleh tingkah laku manusia, jika disalahgunakan tidak hanya berimbas pada satu subjek saja (manusia itu sendiri). Melainkan, akan berimbas pula subjek-subjek yang lainya mengingat tesis dari lingkungan hidup merupakan suatu ekosistem yang saling mempengaruhi.

Namun, jika dikaji lebih jauh dengan berlandaskan pada hipotesa sebelumnya sebagai respon atas pertanyaan hukum mengenai dasar dari dibutuhkannya intrumen pengelolaan lingkungan hidup tersebut. Pada gilirannya, memunculkan pertanyaan hukum lanjutan apakah dengan adanya instrument pengelolaan lingkungan hidup tersebut dapat menekan perilaku menyimpang dari manusia yang merusak lingkungan. Mengingat, keadaan Indonesia saat ini dengan instrumen pengelolaan lingkungan hidup yang tegas, pada tataran fakta empiris tetap terjadi kejahatan lingkungan dan kerusakan lingkungan hidup yang sampai pada taraf

\footnotetext{
${ }^{2}$ Ashabul Kahfi, Kejahatan Lingkungan Hidup, Jurnal al-daulah, Volume 3, Nomor 2, Desember 2014, hlm. 206.

3 Lihat Pasal 1 angkat (1) Undang-Undang Nomor 32 Tahun 2009 Tentang Perlindungan dan Pengelolaan Lingkungan Hidup.

${ }^{4}$ Ashabul Kahfi., Lo.Cit.,
} 
terparah menimbulkan bencana alam sebagai satu rangkaian perintiwa perusakan lingkungan.

Dari fakta empiris tersebutlah, yang selanjutnya menarik perhatian penulis untuk mencari apa yang sejatinya menjadi faktor dari kerusakan lingkungan hidup tersebut dengan menguji dan menghubungkanya pada kasus bencana alam banjir dan tanah longsor yang terjadi di Kabupaten Sentani Jayapura. Analisis tersebut, nantinya akan dikaji dengan memilih pendekatan pada disiplin ilmu "green criminology."5

Pilihan untuk mencari faktor kerusakan lingkungan yang menyebabkan terjadinya bencana alam banjir dan tanah longsor di Kabupaten Sentani Jayapura, dan dengan pendekatan pada disiplin ilmu green criminology tentu bukan tanpa alasan.

Mengingat, selain ambigunya penjelasan mengenai faktor apa yang sejatinya menyebabkan kerusakan lingkungan baik pada kasus-kasus umum, maupun spesifik pada contoh kasus yang di angkat. Hal lain yang juga menjadi pertimbangan adalah bagaimana proyeksi yang dapat ditawarkan untuk mengantisipasi atau sebagai sarana dalam mencegah terjadinya bencana alam akibat pengrusakan lingkungan hidup tersebut.

Sehingga dari uraian diatas, dalam penulisan ini nantinya secara spesifik akan mengkaji perihal bagaimanakah hubungan antara banjir dan tanah longsor di Kabupaten Sentani Jayapura dengan green criminology. Serta, bagaimanakah upaya yang dapat dilakukan untuk mencegah bencana alam banjir di Kabupaten Sentani Jayapura berdasarkan pendekatan green criminology tersebut.

\section{Metode Penelitian}

Dalam penulisan ini, penulis menggunakan teknik penelitian multi metode (triangular method) yang menggabungkan lebih dari satu teknik penelitian atau strategi untuk mempelajari satu atau beberapa fenomena yang saling berhubungan. ${ }^{6}$ Penggunaan multi metode sebagai teknik penelitian, hemat penulis nantinya hanya akan menggunakan dua dari tiga metode tersebut yang ditujukan dengan maksud untuk mencari dan menjawab permasalahan yang diangkat dengan merujuk pada tipologi dengan metode membaca dan perhitungan yang merupakan akhir dari penelitian. ${ }^{7}$.

5 Green Criminology merupakan pendekatan ekologis yang menfokuskan kelestarian lingkungan dan kerusakan lingkungan yang timbul sebagai dampak dari interaksi antar manusia dan lingkungan, dengan menerapkan gagasan tentang etika lingkungan, ekologi, dan hak asasi manusia. White, R. (2007). Green Criminology and the Pursuit of Social and Ecological Justice. Devon: Willan Publishing.

6 Laura Beth Nielses, The Need for Multi-Method Approaches in Empirical Legal Research, The Oxford Handbook of Empirical Legal Research, DOI:10.1093/oxfordhb/9780199542475.013.0040, hlm. 953-954.

7 Scheppele, K.L., 2009, Counting, Reading, Interacting: Focusing on the Activities of the Researcher in Thinking about Methods, Paper presented at the Law and Society Association Early Career Workshop, Denver. 


\section{Pembahasan}

\section{A. Hubungan Green Criminology Dengan Banjir Dan Tanah Longsor Di Kabupaten Sentani Jayapura}

Dari sudat pandang kriminologi, perhatian terhadap kejahatan lingkungan cenderung terabaikan bila dibandingkan dengan masalah-masalah hukum dan ketertiban sosial lainnya. Hal tersebut kirannya disadari, mengingat minimnya pembahasan dan pustaka yang spesifik mengkaji dan menganalisa mengenai kejahatan lingkungan dalam lingkup kriminologi di Indonesia saat ini.

Sementara di sisi lain, timbul kesadaran bahwa Indonesia yang merupakan negara agraris dengan potensi alam yang kaya, tentunya menjadi salah satu faktor tersendiri mengapa kajian terhadap penyalahgunaan pengelolaan lingkungan hidup yang berdampak pada bencana alam dan timbulnya korban, dari sudut padang kriminologi menjadi sesuatu yang dibutuhkan.

Namun sebelum masuk lebih jauh, penting untuk dijelaskan terlebih dahulu terkait apa yang dimaksud dengan kriminilogi, sebelum akhirnya yang nanti dijelaskan pula apa yang dimaksud dengan green criminology sebagai aliran kontemporer dari disiplin ilmu kriminologi.

Krimonologi sebagai disipin ilmu, pertama kali disampaikan oleh P Topinanrd (18301911) yang merupakan antropolog asal Perancis. ${ }^{8}$ Secara etimologi, kriminologi berasal dari kata "crimen" yang berarti kejahatan dan "logos" yang berarti ilmu pengetahuan. ${ }^{9}$ Sehingga berdasarkan defenisi tersebut, secara sederhana dapat dikatakan bahwa kriminologi memiliki arti sebagai disiplin ilmu tentang kejahatan atau penjahat.

Namun dalam tataran doktrin yang disampaikan oleh beberapa pakar, memberikan pengertian yang berbeda terkait apa yang dimaksud dengan kriminologi. W.A Bonger misalnya, yang memberi defenisi kriminologi sebagai "ilmu pengetahuan yang bertujuan menyelidiki gejala kejahatan seluas-luasnya." 10

Masih dalam rangka mendefinisikan kriminologi, pendapat lain dapat pula dilihat dari Frank E Hagan yang mendefenisikan kriminologi sebagai "ilmu atau disiplin yang mempelajari kejahatan dan perilaku kriminal."11 Secara khusus, dijelaskan lebih lanjut bahwa kriminologi berkosentrasi pada bentuk-bentuk perilaku kriminal, sebabsebab kejahatan, dan rekasi masyarakat terhadap aktivitas kriminal. ${ }^{12}$

Seiring dengan perkembangan peradaban, modus operandi, dan bentuk-bentuk kejahatan baru. Kriminologi sebagai disiplin ilmu mulai mengalami kontemporesasi teori guna mengikuti dinamika tersebut. Di antara berbagai aliran kontemporer

\footnotetext{
${ }^{8}$ I.S Susanto, 2011, Kriminologi, Genta Publishing, Yogyakarta, hlm.1.

9 Ibid.,

10 Muhammad Mustafa, 2007, Kriminologi, Fisip UI Press, Depok, hlm. 2.

${ }^{11}$ Frank E Hagan, 2013, Pengantar Kriminologi Teori, Metode, Dan Perilaku Krimnal: Cetakan Ke-Tujuh, Kencana, Jakarta, hlm. 1.

12 Ibid.,
} 
dalam kriminologi tersebut, lahirlah salah satu disiplin yang diistilahkan green criminology atau kriminologi hijau dalam terjemahan Indonesia.

Secara sederhana, green criminology diartikan sebagai cara pandang terhadap kejahatan yang berfokus pada isu-isu lingkungan. Istilah tersebut, pertama kali ditemukan oleh Lynch pada tahun 1990 dan telah diterima secara luas oleh masyarakat sebagai sebuah pemikiran terhadap penegakan hukum kejahatan lingkungan. ${ }^{13}$

Senada dengan Lynch, White yang juga penganut teori kriminologi hijau menyatakan bahwa green criminology berfokus terhadap perusakan yang terkonseptualisasi yang hubungannya antara lingkungan dan manusia serta mahluk hidup yang ada pada sebuah ekosistem. ${ }^{14}$ Oleh karenanya, keterkaitan antara isu lingkungan dan Kriminologi merupakan suatu perkembangan yang timbul dari isu kekhawatiran atas masalah lingkungan.

Dalam tataran konsep, green criminology merupakan pendekatan ekologis yang menfokuskan kelestarian lingkungan dan kerusakan lingkungan yang timbul sebagai dampak dari interaksi antar manusia dan lingkungan, dengan menerapkan gagasan tentang etika lingkungan, ekologi, dan hak asasi manusia. ${ }^{15}$ Dengan konsep tersebut, ruang lingkup dari green criminology berorientasi pada aktifitas analisis isu-isu pelanggaran lingkungan yang secara garis besar terdiri dari: ${ }^{16}$

"Pertama, Kejahatan apa yang terjadi pada lingkungan hidup. Kedua, dampak apa yang ditimbulkan terhadap lingkungan hidup dari kejahatan tersebut. Ketiga, bagaimana terjadinya sebuah kejahatan lingkungan. Keempat, siapakah pelaku yang melakukan kejahatan terhadap lingkungan. Kelima, mengapa pelaku melakukan kejahatan tersebut dan bagaimanakah akibat dari kerusakan lingkungan baik terhadap korban manusia maupun ekosistem tempat terjadinya kejahatan. Keenam, bagaimanakah tanggapan masyarakat terhadap kejahatan lingkungan."

Sehingga dapat ditegaskan bahwa green criminology berhubungan langsung dengan kondisi sosial masyarakat yang mengarah pada kejahatan lingkungan. ${ }^{17}$

Berdasarkan mukadimah di atas, dalam rangka menguraikan hubungan antara green criminology dengan bencana alam banjir dan tanah longsor yang terjadi di Kabupaten Sentani Provinsi Jayapura, penulis menguraikan hubungan tersebut pada ruang lingkup green criminology sebagaimana yang telah diuraikan di atas, serta di dasarkan pada data bencana alam di kabupaten Sentani untuk melihat apakah ruang lingkup tersebut mampu untuk menjawab faktor dari terjadinya becana alam yang dimaksud, sekaligus sebagai jawaban atas pertanyaan mengenai hubungan antara

13 White, R. (2007). Green Criminology and the Pursuit of Social and Ecological Justice. Devon: Willan Publishing.

14 Ibid.,

15 Ibid.,

16 Ibid.,

17 Ibid., 
bencana alam banjir dan tanah longsor yang terjadi di Kabupaten Sentani Jayapura dengan konsep green criminology.

Menurut Direktur Jendral Pengelolaan Daerah Aliran Sungai dan Hutan Lindung (PDASHL) IB Putera Parthama, menyampaikan bahwa pada tahun 1990 tutupan lahan pada daerah aliran sungai (DAS) Sentani seluas 52,305 ha. Selanjutnya, pada tahun 1996 menurun menjadi 52,226 ha, di tahun 2000 menurun kembali menjadi 48.073 ha. ${ }^{18}$ Dari data tersebut, paling tidak dapat disimpulkan bahwa terdapat penurunan luas tutupan lahan sebesar 5\% dari tahun 1996 hingga 2018. ${ }^{19}$

Sementara dalam pendapat lain dari Kepala Pusat Data dan Informasi BNPB Sutopo Purwo Nugroho, menyatakan bahwa banjir dan tanah longsor di Sentani terjadi akibat faktor ulah manusia karena adanya perambahan yang sudah berlangsung sejak tahun 2003 di Cagar Alam Cycloop oleh 43.030 orang, serta penggunaan lahan kering campur pada Daerah Tampungan Air (DTA) seluas 2.415 ha, penebangan pohon untuk pembukaan lahan, perumahan dan kebutuhan kayu, serta adanya tambang galian. ${ }^{20}$

Dari kedua data di atas yang merupakan pemaparan awal terjadinya bencana alam banjir dan tanah longsor di Kabupaten Sentani, yang selanjutnya dihubungkan dengan ruang lingkup Green Criminology, akan menghasilkan analisis pada beberapa poin utama sebagai berikut.

Pertama, analisis ruang lingkup green criminology mengenai kejahatan apa yang terjadi pada lingkungan hidup. Pada poin ini, kejahatan yang terjadi tidak saja merujuk secara spesifik terhadap adanya bencana alam banjir dan tanah longsor yang terjadi di Kabupaten Sentani Jayapura. Melainkan, dari adanya bencana alam tersebut, hal ini sejatinya dipengaruhi dan terdiri atas beberapa perbuatan (perbuatan pidana/kejahatan), yang masing-masing berdiri sendiri-sendiri dalam suatu rangkaian peristiwa. Sehingga, dengan pemaparan tersebut perlu pula untuk dijelaskan lebih lanjut, bahwa bencana alam yang terjadi di Kabupaten Sentani tidak saja menduduki poin sebagai suatu perbuatan jahat (kejahatan). Melainkan, bencana alam di sini memainkan pula peranan sebagai dampak dari kejahatan pada aspek lingkungan hidup.

Sedangkan untuk perbuatan (perbuatan pidana/kejahatan), yang masing-masing berdiri sendiri-sendiri dalam suatu rangkaian peristiwa sebagaimana yang dimaksud di atas. Hal ini, sejatinya masuk pada konstruksi kejahatan penebangan liar atau illegal logging sebagai salah satu faktor utama terjadinya bencana alam tersebut.

Namun yang perlu untuk digaris bawahi, makna penebangan liar atau illegal logging yang dimaksud tersebut tidaklah diartikan secara sempit. Melainkan, hal ini diartikan

18 Ghita Intan, Banjir Sentani Akibat Ulah Manusia,https://www.voaindonesia.com/a/bnpb-banjirbandang-sentani-akibat-ulah-manusia-yang-merusak-alam/4836093.html diakses pada 1 Mei 2021 Pukul 02.25 WIB

19 Ibid.,

20 Ibid., 
secara luas dengan merujuk pada konsep "primary green crimes"21 yang merupakan salah satu dari dua garis besar utama pembagian green criminology.

Sehingga dengan penjelasan yang demikian, dapat disimpulkan bahwa untuk analisis poin pertama ini memberi penegasan kejahatan yang terjadi terhadap lingkungan hidup yang sekaligus sebagai salah satu faktor dari adanya bencana alam banjir dan tanah longsor di Kabupaten Sentani, merupakan kejahatan penebangan liar atau illegal logging yang secara garis besar terdiri atas perbuatan di antaranya: ${ }^{22}$

(1) Penebangan di luar areal kewenangan pemegang hak pengusahaan hutan;

(2) Penebangan melebihi toleransi;

(3) Penyelundupan kayu illegal; serta

(4) Illegal processing. ${ }^{23}$

Di mana, keempat poin di atas yang dijadikan sebagai kesimpulan utama, dirumuskan dengan mempertimbangan data yang dikemukakan di awal, perihal adanya perambahan Cagar Alam Cycloop yang seharusnya menjadi daerah resapan air serta penggunaan lahan kering campur pada Daerah Tampungan Air (DTA) seluas 2.415 ha, penebangan pohon untuk pembukaan lahan perumahan dan kebutuhan kayu, serta adanya penebangan yang ditujukan untuk tambang galian.

Kedua, analisis ruang lingkup green criminology mengenai dampak apa yang ditimbulkan terhadap lingkungan hidup dari kejahatan tersebut. Penjelasan pada sub-kajian ini, memiliki keterkaitan yang erat dengan 4 poin utama (illegal logging) yang telah diuraikan pada poin analisis sebelumnya.

Sehingga, pada kajian analisis dalam poin kedua ini mengenai dampak yang ditimbulkan dari kejahatan lingkungan hidup secara praktis adalah adanya bencana alam banjir dan tanah longsor. Namun, perlu pula untuk ditegaskan bahwa dampak di sini tidak hanya difokuskan pada bencana alam banjir dan tanah longsor yang terjadi di Kabupaten Sentani Jayapura semata. Melainkan, hal ini harus dilihat dari prespektif "secondary green crimes atau yang dalam istilah lain disebut dengan symbiotic green crimes" 24 yang merupakan garis besar poin kedua dari green criminology.

Artinya dalam hal penjelasan mengenai dampak kejahatan lingkungan dalam kajian poin ini, tidak bisa diartikan secara sempit pada konteks terjadinya becnana alam semata. Melainkan, hal ini meliputi pula dampak yang terjadi terhadap korban bencana alam baik yang meninggal dunia maupun yang tidak mendapat penanganan

21 Eamon Carrabine, Paul Iganski, Maggy Lee, Ken Plummer And Nigel South, 2004, Criminology: A Sociological Introduction, Routledge Taylor \& Francis Group, New York And London, hlm. 315-317.

22 Lihat, Eddy O.S Hiariej, Op.Cit., hlm. 8-9.

23 Penebangan kayu dengan menggunakan alat-alat berat dan mesin-mesin termasuk di dalamnya adalah berdirinya industri pemotongan kayu liar atau tanpa ijin. Ibid.,

24 Secondary green crimes atau symbiotic green crimes adalah kejahatan terkait bencana alam. Sebagai missal primary grenn crimes yang mengakibatkan kerusakan lingkungan akan berdampak pada terjadinya bencana alam. Lihat, Eamon Carrabine, Paul Iganski, Maggy Lee, Ken Plummer And Nigel South, Op.Cit., hlm. 318. 
secara baik (penanganan secara psikologis mauapun materil) sebagai pihak yang terdampak langsung atas adanya bencana alam, yang faktornya disebabkan oleh primary green crime tersebut.

Sehingga dengan penjelasan yang demikian, dapat disimpulkan bahwa untuk analisis poin kedua ini mengenai dampak yang ditimbulkan terhadap lingkungan hidup dari kejahatan tersebut, tidak saja pada lingkup terjadinya bencana alam banjir dan tanah longsor yang terjadi di Kabupaten Sentani Jayapura (baik sebagai kejahatan maupun dampak dari adanya kejahatan lingkungan hidup). Melainkan, dampak lain dari adanya kejahatan lingkungan bencana alam tersebut, merujuk pula pada adannya korban bencana alam baik yang meninggal dunia, maupun yang tidak mendapatkan perlakuan secara baik sebagai bentuk "viktimisasi sekunder" 25 atas adanya bencana alam sebagai kejahatan lingkungan.

Ketiga, analisis ruang lingkup green criminology perihal bagaimana terjadinya suatu kejahatan lingkungan. Pada kajian ini, poin analisis yang dijadikan sebagai dasar dalam menilai proses terjadinya bencana alam banjir dan tanah longsor di Kabupaten Sentani Jayapura sebagai suatu kejahatan, didasarkan pada data yang telah dikemukakan sebelumnya.

Secara sederhana, hal ini dapat dideskripsikan dengan melihat gambaran di mana pada tahun 1990 tutupan lahan pada daerah aliran sungai (DAS) Sentani seluas 52,305 ha, yang selanjutnya pada tahun 1996 menurun menjadi 52,226 ha, di tahun 2000 menurun kembali menjadi 48.073 ha. ${ }^{26}$ Dari data tersebut, terlihat bahwa terdapat penurunan luas tutupan lahan sebesar 5\% dari tahun 1996 hingga $2018 .^{27}$

Selain itu, gambaran lain yang juga merupakan pengaruh dari terjadinya bencana alam banjir dan tanah longsor di Kabupaten Sentani Jayapura, terlihat dari adanya perambahan yang sudah berlangsung sejak tahun 2003 di Cagar Alam Cycloop oleh 43.030 orang, serta penggunaan lahan kering campur pada Daerah Tampungan Air (DTA) seluas 2.415 ha, penebangan pohon untuk pembukaan lahan, perumahan dan kebutuhan kayu, serta adanya tambang galian.

Dari uraian kedua data tersebut, kirannya dapat disimpulkan bahwa proses terjadinya bencana alam banjir dan tanah longsor yang terjadi di kabupaten sentani jayapura sebagai bentuk kejahatan lingkungan, terjadi dengan proses yang panjang yang dimulai dengan penebangan liar lahan pada daerah aliran sungai (DAS) dengan dampak penurunan luas tutupan lahan sebesar 5\% dari tahun 1996 hingga 2018. Serta, perambahan yang sudah berlangsung sejak tahun 2003 di Cagar Alam Cycloop oleh 43.030 orang, serta penggunaan lahan kering campur pada Daerah Tampungan Air (DTA) seluas 2.415 ha, penebangan pohon untuk pembukaan lahan, perumahan dan kebutuhan kayu, serta adanya tambang galian.

25 Viktimisasi sekunder atau secondary victimization adalah pengulangan viktimisasi yang lebih cenderung terjadi karena perlakuan dan penanganan terhadap korban yang tidak sesuai. Lorraine Wolhuter, Neil Olley, David Denham, 2009, Victimology: Victimisation and Victim's Rights, Routledge Cavendish, New York, hlm. 33.

26 Ghita Intan, Lo.Cit.,

27 Ibid., 
Keempat, analisis ruang lingkup green criminology mengenai siapakah pelaku yang melakukan kejahatan terhadap lingkungan. Dalam kajian poin ini, kirannya perlu untuk dipahami terlebih dahulu bahwa dalam hal terjadinya suatu kejahatan, penentuan mengenai siapa pelakunya atau siapa subjek yang melakukan kejahatan tentunya menjadi kewenganan penyidik di dalam "system peradilan pidana dalam arti yang sempit." 28 Mengingat, penentuan pelaku kejahatan ini di dasarkan pada adanya penyelidikan terlebih dahulu sebelum akhirnya ditetapkan subjek sebagai pelaku kejahatan tersebut.

Sehingga, dalam poin ini tidak dapat ditegaskan mengenai siapa yang sejatinya menjadi pelaku kejahatan dalam kejahatan lingkungan yang berdampak pada terjadinya banjir dan tanah longsor di Kabupaten Sentani Jayapura, mengingat penjelasan yang telah dikemukakan sebelumnya bahwa hal tersebut merupakan kewenangan penyidik.

Namun, sebagai gambaran dalam penentuan pelaku kejahatan lingkungan berdasarkan pendekatan green criminology. Menekankan, bahwa dalam hal terjadinya bencana alam yang disebabkan oleh kejahatan lingkungan, penentuan pelaku kejahatan dilakukan dengan menganalisis dan mengevaluasi kebijakan terhadap lingkungan, namun tidak saja terhadap kebijakan pemerintah. Melainkan, kebijakan yang ditekankan di sini meliputi dan memperhitungkan pula peran serta masyarakat, korporasi dan pemerintah atas tindakan-tindakan yang membahayakan dan mengakibatkan kerusakan lingkungan. ${ }^{29}$

Sehingga, meskipun tidak dapat ditegaskan siapa yang menjadi pelaku dalam kejahatan lingkungan yang terjadi di Kabupaten Sentani Jayapura. Namun dapat diberi gambaran, bahwa dalam hal terjadinya kejahatan lingkungan, pelaku kejahatan tersebut sejatinya meliputi beberapa subjek utama yakni masyarakat, korporasi dan pemerintah.

Kelima, analisis ruang lingkup green criminology perihal mengapa pelaku melakukan kejahatan tersebut dan bagaimanakah akibat dari kerusakan lingkungan baik terhadap korban manusia maupun ekosistem tempat terjadinya kejahatan.

Dalam poin ini, kajian yang akan dilakukan hanya ditujukan pada bagaimana akibat dari kerusakan lingkungan baik terhadap korban manusia maupun ekosistem tempat terjadinya kejahatan, dan mengesampingkan kajian terhadap motifasi/mengapa pelaku melakukan kejahatan tersebut. Mengingat kajian pada poin sebelumnya yang tidak dapat menegaskan siapa yang menjadi pelaku dalam kejahatan lingkungan di Kabupaten Sentani Jayapura. Tentunya, hal ini berdampak pula pada tidak dapat ditegaskannya poin mengenai mengapa atau motivasi apa yang mendasari pelaku melakukan kejahatan lingkungan tersebut.

28 Sistem peradilan pidana dalam arti yang sempit, diartikan sebagai bekerjanya sub-sub system di dalam penegakan hukum pidana, dilihat dalam Cavadino dan Dignan sebagaimana dikutip oleh Marcus Priyo Gunarto, 2018, Bahan Ajar Hukum Pidana: Sistem Peradilan Pidana, Fakultas Hukum, Unersitas Gadjah Mada, Yogyakarta.

29 Lihat Eddy O.S Hiariej, Op.Cit., hlm. 8. 
Selanjutnya, mengenai akibat dari kerusakan lingkungan terhadap korban manusia dari adanya banjir dan tanah longsor di Kabupaten Sentani Jayapura, hal ini akan diuraikan kedalam dua garis besar utama.

Pertama, kerugian materil akibat kejahatan yang berdampak pada kerusakan lingkungan terhadap korban manusia dari adanya banjir dan tanah longsor di Kabupaten Sentani Jayapura. Dalam garisbesar pertama ini, dari adanya becana alam tersebut mengaibatkan kerugian sebesar Rp454 miliar, dengan dampak terbesar terhadap kerusakan permukiman yang mencapai nilai Rp 252 miliar. Serta, kerugian di sektor infrastruktur yang mencapai Rp174 miliar, sektor ekonomi Rp 22,6 miliar, sosial Rp4 miliar dan lintas sektor Rp1 miliar. Selain itu tercatat adanya 1.770 unit rumah rusak. ${ }^{30}$

Kedua, kerugian terhadap nyawa dan fisik akibat kerusakan lingkungan terhadap korban manusia dari adanya banjir dan tanah longsor di Kabupaten Sentani Jayapura. Dalam garisbesar kedua ini, dari adanya becana alam tersebut hal ini berdampak pada adanya 112 orang meninggal dunia, 82 orang hilang, 917 orang luka-luka, 8.008 orang mengungsi dan $33.161 \mathrm{KK}$ terdampak. ${ }^{31}$

Sedangkan untuk kerusakan yang diakibatkan kejahatan lingkungan terhadap ekosistem tempat terjadinya bencana alam, dalam hal ini dampak terhadap ekosistem dari adanya bencana alam banjir dan tanah longsor di Kabupaten Sentani Jayapura. Sejatinya, hal ini tidak dapat secara langsung dirumuskan dampak seperti apa yang terjadi pasca adanya bencana alam tersebut terhadap ekosistem yang ada di Kabuaten Sentani. Melainkan, dibutuhkan penelitian lapangan yang lebih komprehenif sebelum akhirnya dapat memberi suatu kesimpulan yang tegas perihal dampak bencana alam tersebut baik secara langsung maupun tidak langsung terhadap kerusakan ekositem.

Kendatipun demikian, perlu pula untuk dijelaskan bahwa sudah menjadi hal yang pasti bahwa terjadinya suatu bencana alam baik secara langsung maupun tidak langsung akan membawa dampak terhadap keseimbangan ekosistem lingkungan. Mengingat, lingkungan yang merupakan kombinasi antara kondisi fisik dan non fisik, yang cakupannya meliputi segala hal dan keadaan, serta mencangkup eksistensi manusia dan sekitarnya, dalam hal terjadinya bencana alam sebagai bentuk ketidakseimbangan, pada akhirnya mempengaruhi kelangsungan ekosistem dan peri kehidupan manusia itu sendiri.

Keenam, analisis ruang lingkup green criminology perihal bagaimanakah tanggapan masyarakat terhadap kejahatan lingkungan. Hemat penulis, kajian dalam poin ini kirannya belum dapat terjawab mengingat terhadap poin dalam ruang lingkup keenam ini harus dilakukan penelitian yang lebih mendalam dan terlibat langsung

30 Fahreza Rizki, BNPB: Kerugian Banjir Bandang Di Sentani Capai Rp454 Miliar, https://www.google.co.id/amp/s/news.okezone.com/amp/2019/03/29/340/2036798/bnpbkerugian-banjir-bandang-di-sentani-capai-rp454-miliar Diakses pada 5 Mei 2021 pukul 14:35 W.I.B.

31 Newswire, Kerugian Akibat Banjir Sentani Rp454Miliar, https://www.google.co.id/amp/s/m.bisnis.com/amp/read/20190330/15/906162/keru gian-akibat-banjir-sentani-capai-rp454-miliar, Diakses pada 5 Mei 2021 pukul 14:52 W.I.B. 
dengan masyarakat yang menjadi bagian dan korban dalam kejahatan lingkungan tersebut.

Sehingga dari pemaparan diatas, kendatipun belum menjawab beberapa poin dari ruang lingkup green criminology kaitannya dengan contoh kasus yang diangkat. Namun, berdasarkan beberapa poin analisis lainnya, kiraanya sudah memberi suatu jawaban yang dapat ditarik sebagai suatu kesimpulan bahwa hubungan antara green criminology dengan bencana alam banjir dan tanah longsor di Kabupaten Sentani Jayapura, terletak pada faktor dalam kejadian faktual yang memiliki keterkaitan dengan ruang lingkup green criminology tersebut.

\section{B. Proyeksi Sebagai Tawaran Dalam Upaya Pencegahan Banjir Dan Tanah Longsor Di Kabupaten Sentani Jayapura}

Pasca diuraikannya hubungan antara bencana alam yang terjadi di Sentani dengan pendekatan green criminology. Selanjutnya, penulis akan mengkaji mekanisme atau upaya apa yang dapat dilakukan untuk mecegah dan menanggulangi bencana alam tersebut.

Sebelum masuk lebih jauh, perlu kirannya untuk dijelaskan terlebih dahulu bahwa terhadap pendekatan yang digunakan pada penelitian ini yakni green criminology. Sejatinya, pendekatan tersebut lebih cocok digunakan sebagai sarana pencegahan daripada sarana penanggulangan dalam kejahatan lingkungan. Mengingat, dalam hal terjadinya kasus-kasus kejahatan lingkungan hidup, penanggulangan terhadap kejahatan tersebut cenderung lebih sulit untuk dimintakan pertanggungjawaban.

Kesulitan sebagaimana yang dimaksud di atas, sejatinya terjadi karena dalam teori hukum lingkungan, prinsip prevention atau pencegahan yang merupakan sarana utama sebelum masuk pada sarana penanggulangan, memiliki beberapa kendala utama yang terkait dengan kejahatan tersebut sulit untuk dibuktikan, biaya mahal, dan dalam pembuktiaanya membutuhkan teknologi yang canggih. Sehingga dengan kendala tersebut, dalam penanganan kejahatan lingkungan hidup umumnya hanya sampai pada tahap pencegahan. Mengingat, dalam tahap pencegahan, problematika yang ditemukan sudah sangat kompleks.

Namun, mengingat contoh kasus yang penulis angkat terkait dengan bencana alam banjir dan tanah longsor di Kabupaten Sentani Jayapura telah terjadi. Sehingga, kajian terhadap upaya penanggulangan bencana alam sebagai dampak dari adanya kejahatan di sektor lingkungan hidup kirannya tidak dapat dihindarkan.

Selanjutnya untuk menjawab rumusan masalah pada poin ini, penulis akan membagi kajian tersebut menjadi 2 sub pembahasan utama. Pertama, terkait dengan upaya pencegahan yang dapat dilakukan terhadap bencana alam yang terjadi di Sentani. Kedua terkait upaya penanggulangan yang dapat dilakukan terhadap bencana alam yang terjadi di Sentani. Pembagian ini ditujukan untuk lebih memudahkan dalam membedakan mana yang masuk sebagai upaya pencegahan dan mana yang masuk sebagai upaya penanggulangan. Walaupun, terhadap kedua mekanisme tersebut tidak dapat dipisahkan. 
UIRLawReview. 5(1): 59-75

\section{(1) Upaya Pencegahan Yang Dapat Dilakukan Terhadap Bencana Alam Yang Terjadi Di Sentani}

Upaya dalam pencegahan kejahatan lingkungan atau uapaya prefentif, secara sederhana diartikan sebagai mekanisme yang dilakukan untuk mencegah atau meghalangi agar suatu perbuatan yang terkait dengan kejahatan pada sektor lingkungan hidup tidak terjadi.

Namun, sebagaimana yang telah dikemukakan di awal terkait contoh kasus yang penulis angkat yaitu bencana alam banjir dan tanah longsor di Kabupaten Sentani Jayapura telah terjadi. Sehingga, dalam upaya pencegahan yang nantinya akan penulis uraikan sebagai proyeksi, sejatinya hanya memberi pemaham mengenai bagaimana seharusnya upaya terhadap pencegahan kejahatan lingkungan di Sentani dilakukan dengan prediksi dan simulasi sebelum kejahatan lingkungan yang berdampak pada bencana alam tersebut terjadi.

Selanjutnya dalam rangka menjabarkan proyeksi bagi upaya pencegahan tersebut, penulis menggabungkan dua aliran dalam disiplin ilmu kriminologi yang akan digunakan. Yaitu, pendekatan green criminology sebagai upaya untuk mencari faktor kejahatan lingkungan. Serta, hygiene criminal yang nantinya ditujukan sebagai usaha untuk mencegah terjadinya kejahatan. ${ }^{32}$

Merujuk kembali pada faktor-faktor terjadinya kejahatan lingkungan yang menyebabkan bencana alam banjir dan tanah longsor Di Kabupaten Sentani Jayapura sebagaimana yang telah dikemukakan di awal, yang terdiri dari: Pertama, faktor penurunan luas tutupan lahan sebesar 5\% dari tahun 1996 hingga 2018. ${ }^{33}$ Kedua, faktor ulah manusia karena ada perambahan yang sudah berlangsung sejak tahun 2003 di Cagar Alam Cycloop oleh 43.030 orang. Ketiga, faktor penggunaan lahan kering campur pada DTA seluas 2.415 ha, penebangan pohon untuk pembukaan lahan, perumahan dan kebutuhan kayu, serta adanya tambang galian. ${ }^{34}$

Memperhatikan data dari faktor terjadinya bencana alam di Kabupaten Sentani sebagaimana yang diuraikan di atas. Kirannya dipahami, bahwa kejahatan terhadap lingkungan hidup tersebut telah berlangsung sejak lama yang kurang lebih dimulai dari tahun 1996.

Namun, faktor tersebut yang hemat penulis dilabeli sebagai faktor kejahatan lingkungan dan berdampak pada adanya bencana alam di Kabupaten Sentani, pada faktanya hal ini seolah-olah tidak mendapat tanggapan. Tidak ditanggapinya problem tersebut, dapat dilihat dari data penurunan DAS yang hingga tahun 2018 masih berlangsung dengan presentase sebanyak 5\%. Argumentasi penulis sebagai prediksi mengapa penurunan kulaitas

\footnotetext{
${ }^{32}$ Eddy O.S Hiariej, Op.Cit, hlm. 6.

33 Ghita Indah, Lo.cit.,

34 Ibid,
} 
lingkungan hidup di Kabupaten Sentani Jayapura tidak mendapat tanggapan, paling tidak dapat diuraikan pada beberapa hal utama.

Pertama, penurunan kulaitas lingkungan hidup disebabkan turut sertanya pemerintah dalam terjadinya tindakan kejahatan lingkungan. Arguumentasi penulis ini, berdasar pada temuan dari organisasi Wahana Lingkungan Hidup (WALHI), yang menyatakan "instansi pemerintah di Papua maupun Pemerintah Pusat, mengeluarkan izin-izin konsesi kepada korporasi atas nama Negara". ${ }^{35}$ Izin konsesi yang dikeluarkan oleh pemerintah baik itu pemerintah Papua maupun Pemerintah Pusat dilakukan di daerah Gunung Cycloop yang patut diketahui adalah daerah cagar alam.

Sehingga, sebagai upaya pencegahan dengan dasar pada uraian terhadap faktor pertama tersebut, penulis menarik suatu proyeksi sebagai solusi yang dapat dijadikan sebagai pertimbangan bagi upaya pencegahan terhadap kejahatan lingkungan hidup. Proyeksi yang penulis tawarkan sebagai solusi tersebut, kriannya bersesuaian pula dengan upaya yang ditawarkan oleh Kementrian Lingkungan Hidup dan Kehutanan (KLHK), yang seara garis besar terdiri atas beberapa poin utama sebagai berikut:

"Pertama, mengembalikan kawasan hutan sesuai dengan fungsinya. Kedua, melakukan review tata ruang berdasarkan pertimbangan pengurangan risiko bencana dan mengembangkan skema adaptasi di titik banjir. Ketiga, internalisasi program rehabilitasi lahan di hulu dan tengah DAS terutama kawasan hutan ke dalam indikasi program pada tata ruang. Keempat, internalisasi program konservasi tanah dan air berupa Saluran Pembuangan Air (SPA) di lahan pertanian dan permukiman untuk meningkatkan pengaturan sehingga menurunkan potensi longsor dan akumulasi air pada waktu yang pendek." ${ }^{\prime 36}$

Kedua, penurunan kulaitas lingkungan hidup yang disebabkan turut sertanya masyarakat dalam terjadinya kejahatan lingkungan. Argumentasi penulis untuk meletakan masyarakat sebagai bagian dari terjadinya kejahatan lingkungan, di dasarkan pada data yang telah dikemukakan di awal perihal faktor terjadinya bencana alam di Kabupaten Sentani Jayapura, yang salah satunya dipengaruhi oleh eksploitasi besar-besaran dari masyarakat selain dari tindakan pemerintah dan korporasi itu sendiri.

Namun, peran serta masyarakat dalam hal terjadinya kejahatan lingkungan sebagaimana yang dimaksud dalam poin ini, hemat penulis berbeda dengan peranan korporasi dan negara dalam tururt serta terjadinya kejahatan lingkungan.

${ }^{35}$ Fahreza Rizki, Lo.Cit.,

${ }^{36}$ Pejabat Pengelola Informasi dan Dokumentasi Kementrian Lingkungan Hidup Dan Kehutanan (PPIDKLHK), Siaran Pers Penyebab Banjir Bandang Sentani Di Komisi IV DPR RI, https://jpp.go.id/humaniora/lingkungan-hidup/331047-empat-rekomendasi-klhk-untukmengatasi-banjir-di-wilayah-das Diakses pada Kamis, 7 Mei 2021 pukul 03:45. 
Perbedaan ini, paling tidak dipengaruhi oleh pemikiran apakah masyarakat sebagian besar memahami dampak yang ditimbulkan akibat kegiatan eksploitasi lingkungan secara besar-besaran tersebut.

Sehingga, untuk upaya pencegahan kejahatan lingkungan hidup yang dapat dilakukan terhadap masyarakat, penulis mencoba menawarkan proyeksi dengan upaya pemberian pemahaman dan sosialisasi terkait green criminology tersebut terhadap masyarakat.

Proyeksi sebagai tawaran dalam upaya pencegahan melalui mekanisme sosialisasi green criminology terhadap masyarakat di tempat terjadinya kejahatan sebagaimana yang dimaksud di atas, paling tidak di dasari atas adanya penelitiaan terlebih dahulu yang dilakukan oleh Dasim Budimansyah, Susan Fitriasari, Dwi Iman Mutaqin, Dede Iswandi mengenai efek gerakan green criminology terhadap kesadaran hukum masyarakat dalam mencegah tindak kejahatan lingkungan.

Dari penelitian tersebut diketahui, bahwa mekanisme sosialisasi akan lebih efektif untuk pencegahan kejahatan lingkungan karena hal tersebut memberi dampak yang signifikan dalam mengubah pola perilaku masyarakat dalam rangka mewujudkan tanggung jawab warganegara terhadap lingkungan. Sehingga dengan dilaksanakannya proyeksi ini, diharapkan mampu memberi pemahaman terhadap masyarakat dengan cara yang sederhana perihal beberapa prinsip utama dalam teori ekologisentrime yang relevan. ${ }^{37}$

Prinsip-prinsip sebagaimana yang dimaksud di atas, di dasarai pada adanya penghargaan terhadap hak alam dan dilatarbelakangi oleh krisis ekologi yang bersumber pada cara pandang dan perilaku antropologi antara lain (1) sikap hormat terhadap alam (respect for nature); (2) tanggung jawab (moral responbility for nature); (3) prinsip kasih sayang dan kepedulian terhadap alam (caring for nature); dan (4) prinsip hidup sederhana dan selaras dengan alam. ${ }^{38}$

Selain itu, terhadap upaya pencegahan yang penulis tawarkan ini. Kirannya, hal ini tidak dapat dilepaskan sepenunya dengan upaya penanggulangan karena kedunya saling reversible. Sehingga dari upaya pencegahaan ini, seandainya tidak terlaksana dengan baik, masih dapat diupayakan penanggulangan terhadap kejahatan lingkungan khususnya pada bencana alam yang terjadi di Kabupaten Sentani yang akan dibahas pada sub kajian selanjutnya

${ }^{37}$ Dasim Budimansyah Dkk, Efek Gerakan Green Criminology Terhadap Kesadaran Hukum Masyarakat Dalam Mencegah Tindak Kejahatan Lingkungan, Conference: 7th UPSI UPI Conference At: Tanjong Malim, Mlaysia, hlm. 9-10.

${ }^{38}$ Rahayu, T. Puji, 201, Enskilopedia Seri Desa-Kota. Semarang: Aneka Ilmu, hlm. 1. 


\section{Kesimpulan}

Dari uraian singkat yang penulis sampaikan diatas, paling tidak dapat ditari 2 (dua) kesimpulan utama yaitu: Pertama, hubungan antara Green Criminology dan bencana alam banjir serta tanah longsor di Kabupaten Sentani seperti dalam uraian rumusan masalah pertama adalah factor dalam kejadian factual serta dikaitkan dengan ruang lingkup Green Criminology menjadi penjelasan hubungan antara Green Criminology dan bencana alam banjir serta tanah longsor di Kabupaten Sentani.

Kedua, Upaya pencegaha sebagai tawaran proyeksi, secara garis besar terdiri atas beberapa poin utama, yaitu: Pertama, mengembalikan kawasan hutan sesuai dengan fungsinya. Kedua, melakukan review tata ruang berdasarkan pertimbangan pengurangan risiko bencana dan mengembangkan skema adaptasi di titik banjir. Ketiga, internalisasi program rehabilitasi lahan di hulu dan tengah daerah aliran sungai (DAS) terutama kawasan hutan ke dalam indikasi program pada tata ruang. Keempat, internalisasi program konservasi tanah dan air berupa Saluran Pembuangan Air (SPA) di lahan pertanian dan permukiman untuk meningkatkan pengaturan sehingga menurunkan potensi longsor dan akumulasi air pada waktu yang pendek. Kelima, untuk pencegahan terhadap kejahatan lingkungan yang dilakukan oleh masyarakat dengan pemberian pemahaman terkait green criminology tersebut kepada masyarakat. 


\section{Daftar Pustaka}

Carrabine, Eamon, Paul Iganski, Maggy Lee, Ken Plummer And Nigel South, 2004, Criminology: A Sociological Introduction, Routledge Taylor \& Francis Group, New York And London.

Hagan, Frank E, 2013, Pengantar Kriminologi Teori, Metode, Dan Perilaku Krimnal: Cetakan Ke-Tujuh, Kencana, Jakarta.

Hiariej, Eddy O.S, 2018, Asas-Asas Hukum: Bahan Ajar Teori dan Filsafat Hukum, Fakultas Hukum, Universitas Gadjah Mada.

Gunarto, Marcus Priyo, 2018, Bahan Ajar Hukum Pidana: Sistem Peradilan Pidana, Fakultas Hukum, Unersitas Gadjah Mada, Yogyakarta.

Mustafa, Muhammad, 2007, Kriminologi, Fisip UI Press, Depok.

Puji, Rahayu, T, 2001, Enskilopedia Seri Desa-Kota. Semarang: Aneka Ilmu.

R, White, (2007). Green Criminology and the Pursuit of Social and Ecological Justice. Devon: Willan Publishing.

Susanto, I.S, 2011, Kriminologi, Genta Publishing, Yogyakarta.

Wolhuter, Lorraine, Neil Olley, David Denham, 2009, Victimology: Victimisation and Victim's Rights, Routledge Cavendish, New York, hlm. 33.

Ashabul Kahfi, Kejahatan Lingkungan Hidup, Jurnal al-daulah, Volume 3, Nomor 2, Desember 2014, hlm. 206.

Laura Beth Nielses, The Need for Multi-Method Approaches in Empirical Legal Research, The Oxford Handbook of Empirical Legal Research, DOI:10.1093/oxfordhb/9780199542475.013.0040, hlm. 953-954.

Scheppele, K.L., 2009, Counting, Reading, Interacting: Focusing on the Activities of the Researcher in Thinking about Methods, Paper presented at the Law and Society Association Early Career Workshop, Denver.

Dasim Budimansyah Dkk, Efek Gerakan Green Criminology Terhadap Kesadaran Hukum Masyarakat Dalam Mencegah Tindak Kejahatan Lingkungan, Conference: 7th UPSI UPI Conference At: Tanjong Malim, Mlaysia, hlm. 9-10.

Ghita Intan, Banjir Sentani Akibat Ulah Manusia, https://www.voaindonesia.com/a/bnpbbanjir-bandang-sentani-akibat-ulah-manusia-yang-merusak-alam/4836093.html diakses pada 1 Mei 2021 Pukul 02.25 WIB

Fahreza Rizki, BNPB: Kerugian Banjir Bandang Di Sentani Capai Rp454 Miliar, https://www.google.co.id/amp/s/news.okezone.com/amp/2019/03/29/340/2036798 /bnpb-kerugian-banjir-bandang-di-sentani-capai-rp454-miliar Diakses pada 5 Mei 2021 pukul 14:35 W.I.B.

Newswire, Kerugian Akibat Banjir Sentani Rp454Miliar,https://www.google.co.id/amp/s/m.bisnis.com/amp/read/20190330/15 1906162/kerugian-akibat-banjir-sentani-capai-rp454-miliar, Diakses pada 5 Mei 2021 pukul 14:52 W.I.B. 
UIRLawReview. 5(1): 59-75

Pejabat Pengelola Informasi dan Dokumentasi Kementrian Lingkungan Hidup Dan Kehutanan (PPID-KLHK), Siaran Pers Penyebab Banjir Bandang Sentani Di Komisi IV $D P R R I$, https://jpp.go.id/humaniora/lingkungan-hidup/331047-empat-rekomendasiklhk-untuk-mengatasi-banjir-di-wilayah-das Diakses pada Kamis, 7 Mei 2021 pukul 03:45. 